\title{
PROMOTION OF QUALITY MANAGEMENT IN PUBLIC ADMINISTRATION
} - THE APPROACH OF CZECH CENTRAL GOVERNMENT

\section{David Špaček}

Masaryk University, Faculty of Economics and Administration, Lipová 41a, Brno, Czech Republic, e-mail: david.spacek@econ.muni.cz

\begin{abstract}
The first part of the paper summarizes the specifics of quality and its management in public administration. The second part introduces the approach of the Czech central government to quality management promotion in public administration with regard to classification of approaches proposed by Löffler and Vintar (2004). The approach is more converging to Löffler and Vintar's 'hands-on' and supportive approach rather than to passive or control-orientation approaches.
\end{abstract}

Key words: quality management promotion, public management, Czech public administration reform.

\section{JEL Classification: H79}

DOI: $10.2478 / \mathrm{v} 10135-011-0002-2$ 


\section{PROMOTION OF QUALITY MANAGEMENT IN PUBLIC ADMINISTRATION - THE APPROACH OF CZECH CENTRAL GOVERNMENT}

\section{David Špaček ${ }^{1}$}

\section{Introduction}

The quality is omnipresent regardless how hard it is to define it in a universally acceptable way because of its summarizing features. Service quality has become a key marketing tool for achieving competitive differentiation and fostering customer loyalty according to Zeithaml and Parasuraman (2004). Based on empirical findings and the conceptual development of service quality, quality is now often believed to be the antecedent of satisfaction, particularly through positive quality judgements of consumers according to Schneider and White (2004). Similar ideas can be heard not only in the private sector, where quality is vital in order to survive the competition, apparently they are emerging more and more also in the public sector; one can read about them in public administration reform strategies, some speak even about the quality movement in public administration across (Löffler and Vintar, 2004).

In public administration, the concept of competitiveness may be problematic due to the nature of the administrative context. Public administration represents a social, intersectoral and multidisciplinary phenomenon that is different from the private administration in a certain respect. Public administration consists of a large group of institutions and a vast amount of activities of societal management and coordination of the executive power. The main function of public administration is to guarantee (and therefore to manage) the sustainable realization of functions that are assigned to public sector by political decision-making which is not always stable or innovative. Administrative activities are decided politically and exercised by a specific group of employees (civil servants) on the basis of law that prescribes and also limits the scope of managerial practices and the extent of possible competition in service delivery. Although some claim that the concept of political and administrative dichotomy (separation) is outdated (e.g. Hughes, 2003) it may be apparent in administrative contexts of post-communist countries which have not always represented a systemic part of comparative public administration studies yet.

According to Caddy and Vintar (2002), efforts to improve quality in public administration are undertaken in the hope of achieving a number of tangible benefits like a culture of continuous improvement, better customer service, greater strategic thinking about missions and goals, or sustained levels of performance. Specifics of public administration influence concepts of quality that have been described and methodically elaborated in various quality management instruments for public authorities. The features of a negotiated concept of quality as described for example by Gaster and Squires (2003) are visible in various quality management instruments that

\footnotetext{
${ }^{1}$ Masaryk University, Faculty of Economics and Administration, Lipová 41a, 60200 Brno, Czech Republic, e-mail: david.spacek@econ.muni.cz.
} 
have become a part of today's official national lists used also for purposes of national quality awards. The concept of negotiated quality tries to address the following key question of quality in the public sector: "how to balance the complex needs, wants and demands of individuals, communities and society as a whole, with the capacity, resources, legal requirements and technical abilities of organizations and individuals responsible for achieving good quality services?" (Gaster and Squires, 2003, p. 42). Analogies of this question are reflected in various quality management instruments like excellence models, Local Agenda 21, BSC etc., and require making public decision- and policy-making more participatory and inclusive for internal, as well as external stakeholders.

Certainly the implementation of the negotiated concept of quality is demanding, some may claim even unrealistic, but for sure it is preventive. Similar approaches to quality integrate the focus of Beltrami's three phases of the evolution of quality in the public sector (quality in the sense of respect of norms and procedures, quality in the sense of effectiveness, and quality in the sense of customer satisfaction; Löffler, 2002, pp. 21 23), go beyond them and question the real situation and limits of inclusiveness, transparency, rationality, legitimacy and thus also efficiency in public administration. The negotiated concept of quality directly springs from the specific accountability of the government - "Government must be accountable to the larger public interest - not merely the self-interest of individual customers or consumers", as Denhardt and Denhardt point out (2003, p. 60). Flynn (2001, pp. 202 - 204) warns of contradictions in customer/citizen orientation when arguing potential tensions in a) relationships between the quality and budgets (where the word precondition is more suitable); b) relationships between politicians, service providers (and managers) and users; and c) potential tradeoffs between equity of treatment and customization. Milakovich (1995), who describes the concept of total quality public service, gives also notice that reconciling the competing demands of diverse interest groups forces politicians to reconcile multiple, vague and often conflicting goals. According to him, "often the net result is that nothing gets done" (p. 159).

The concept of negotiated quality is based on trust, participation accessible to stakeholders, necessary coordination and thus communication that try to explain and learn what is and what is not feasible. The concept depends on partnership rather than on strict enforcement by those entrusted with public power from the supply-centred view. It also requires surveying and evaluation of stakeholders' needs. Similar principles establish basis of Denhardt and Denhardt's New Public Service (2003). Beam (2001, p. 32) warns that not all participation is meaningful and, therefore, not all participations lead to satisfaction of those affected nor to improving quality or increasing productivity - "meaningful participation occurs when the agency personnel and affected citizens coproducing the organization's product have significant power in matters of central importance to them." Flynn (2002) recommends considering the nature of the service ${ }^{1}$ developing and maintaining a relationship which gives the recipients or users of the service as much control over the service as they want (and can be allowed to have). He also discusses the opinion of Willcox and Harrow that service

\footnotetext{
${ }^{1}$ He differentiates services that are protective (fire, child protection); services concerned with organizing access to entitlements (social security); and services concerned with helping people to have fuller lives (adult education). (p. 191).
} 
can be more responsive if there is a consumer relationship than if the relationship is one of the dependency. Flynn also warns that some managers use the fact that a service is defined by law as a reason for not allowing users of the service to have a choice.

When discussion about specifics of quality management in public administration is spreading out, one must be aware of the fact that quality management instruments which have been modified for public authorities are not established on different basis than quality instruments of the private sector. They require real rather than formal systemic approach which takes into account both internal and external stakeholders. Their general aim is to balance internal capacities of an organization with requirements and capacities of external environment which is traditionally elaborated in general management theories. The questions necessary to answer are: How is quality defined? How is it measured? How is it put into practice? How is it maintained? Whose quality is it? (Gaster and Squires, 2003, p. 39).

The question "How is quality maintained in public administration?" in particular raises questions about approach of central government to quality management, particularly its promotion and evaluation of existing practices. This paper discusses features of Czech central government's approach to quality management promotion in public administration with regards to typology of approaches proposed by Löffler and Vintar (2004), who differentiated following approaches of central government:

a) central governments with a largely passive role,

b) central government taking a supportive role,

c) central government taking a control-oriented approach,

d) central government using a 'hands-on' approach.

\section{Central government approach to quality management in public administration}

Czech central government has not been passive in promotion of quality management in general, neither in public administration (Špaček and Nunvářová, 2009). Building on the categorisation of roles which central government can adopt, we may say that the Czech approach is more converging to the "hands-on approach", some features of the supportive role can be found here as well. Czech central government has promoted some instruments, but had not perceived quality instruments group as limited only to them, which is a characteristic of the Löffler and Vintar's hands-on approach. Several initiatives promoting rather large group of quality management instruments have been launched, but none of them emphasized what had been pointed out with regard to the "supportive role" of central government - compulsory strategic management framework of vast majority of public authorities as was the case of the Irish Public Service Management Act of 1997, which was based on the Strategic Management Initiative with its more systemic requirements on Quality Customer Service and Customer Action Plan (Humphreys, 2004).

The main features of the Czech central government approach to quality management in public administration can be summarized as follows: 


\subsection{Governments approved national policy and strategies on quality support in public administration}

European trends of quality management in public administration were introduced very briefly in the Conception of Public Administration Reform which was "taken into account" by government in 1999. The main aim of the conception was to propose alternatives of territorial public administration organization in order to solve the constitutional creation of 14 regions (including the capital city of Prague) in 1997 without any further specification of their responsibilities. Proclamations on quality have been brought to the stage particularly by the later National policy on quality support in the Czech Republic ("National quality policy") which was approved by the resolution of government no. 458 in 2000 . This policy referred to quality initiatives in the private and the public sectors and was elaborated in twinning expert cooperation with the European Union. The policy was also approved in order to harmonize Czech practice with international initiatives (including the European Charter of Local Self-Government which was incorporated into Czech law in 1999). In this era of the Czech candidateship to the EU, the European pressures were often stressed in the National quality policy, particularly in the European quality charter, role of education, benchmarking and learning from good practices, the EFQM excellence model together with the ISO 9000 series were among the most emphasized in the policy. Special attention was paid to quality support in the army in order to harmonize this area with quality assurance in NATO which the country entered in 1999.

On the basis of the 2000's National quality policy, the Council of the Czech Republic for Quality (thereinafter "Council for quality") was established within the responsibility of the Ministry of Industry and Trade in order to coordinate activities of "state and nonstate bodies" within the area of the quality policy, and to help the Government as a consultative, initiative and coordination body. Members of the Council for quality shall include ministerial deputies, representatives of central standardisation authorities, nongovernmental and non-profit organisations from the field of quality and of trade unions. Besides the Council for Quality, the National Information Centre for Quality Support ("NIS-PJ", later renamed as "NIS-PK") was also created together with its Consultation Centre for Statistical Methods. Also, a civic association Czech Association for Quality was created in order to support the quality practice in the private, as well as in the public sector.

In 2002, the government approved the Czech Quality Program (CzQ, i.e. the proposal of program for support of quality goods selling and quality services delivery) by its resolution no. 685 which also emphasized the role of consumer protection in accordance with the former Conception of Consumer Policy of the Ministry of Industry and Trade for the period $2001-2005$. This initiative referred particularly to the assurance and inspection role of public administration, not to quality in public administration itself and will not be discussed in the paper to a greater detail.

Quality management in public administration was also highlighted in the period of project management in "reform and modernization" of central administration level which started in March 2004, when the government approved its resolution no. 237 on the Process and main directions of reform and modernization of central state administration. This document repeated most of aims declared by previous governments 
and its intent is still echoed in initiatives of the current government that are introduced below. For example the project C.1 required implementation and development of quality management in central state administration level. This project presumed two phases of its realization - it was supposed that managers of central authorities would be educated and trained during the first phase, and Common Assessment Framework methodology and benchmarking would be implemented during the second phase.

In 2003, the Government's Council for Sustainable Development was also established by the government's resolution no. 778. In April 2004, its working group on Local Agenda 21 was appointed in order to make Local Agenda 21 a common instrument of Czech public administration. This group produced a list of binding criteria for evaluation of Local Agenda 21 practice in the Czech Republic.

Relatively strong policy focus of the centre on improving quality of public services was apparent in the Czech policy particularly in the period 2000 - 2005. In December 2000, the government set requirements in its Updated preview of legislative work for 2002 to legislatively solve the planned abolishment of district authorities, which had been executed state administration in districts since 1990, and to address the transfer of their competencies to municipal and regional self-government which has been executed by self-government as well as state administration in accordance with the created joined model of public administration in the territory (in case of municipalities since 1990, in case of regions since 2001). In February 2002, a Bill on standardization of selected public services was approved by the government by its resolution no. 164. The Bill attempted to address the situation when no legal definition of "a public service" and "parameters of availability of public services" were not incorporated in Czech legislation. The Bill defined public services (its text stressed several times that it was doing so in accordance with prepared European Comission's directive of services provided in public interest) as services created, organized or regulated by public authorities in order to ensure their delivery in the way that is supposed to be necessary to satisfy needs of society while respecting the principle of subsidiarity at the same time. The Bill aimed at the prescription of the list of services and quantitative and qualitative criteria of their provision that would be binding for municipalities and regions ("guarantors"), as well as the mechanism of control. The Bill prescribed standards of the following public services: a) social services, b) medical rescue service, c) antialcoholism and anti-toxicomanic catch stations, d) accessing of museum and fine arts collections, e) librarian and information services, f) transportation service. Other public services were supposed to be left for specification by (existing and future) special acts, or were not appropriate for standardization according to the submitters of the Bill.

The resolution from February 2002 required the prime minister, minister of labour and social affairs, minister of transport and communications, minister of culture and minister of healthcare together with minister of interior to elaborate and submit bills on necessary legislation till the end of July 2002. The resolution stated that till the end of November 2002, an analysis of possibilities of public services standardization had to be elaborated and submitted to government. In December 2002, the government realized that the deadline was set too tight and expanded the first deadline till the end of March 2003, and the second deadline till the end of May 2003 (by its resolution no. 1259). 
Ministry of Interior elaborated the Methodical Guide for Public Services Analysis in order to secure uniform steps and to stipulate the schedule of necessary activities. The ministry was criticizing cooperation of some ministries because it had obtained the last supplementary documents necessary for the analysis at the end of April 2003. The analysis of possibilities of public services standardization was submitted to government in late July 2003. Because of complaints of some ministries, the Ministry of Interior was asked to change the analysis and resubmit it in August. The final version of the analysis was "taken into account" by the government by its resolution no. 848/2003, which also required a strategy for support of public services availability and quality to be elaborated till the and of March 2004.

This strategy was "taken into account" by the government in September 2004 (by its resolution no. 824) which enumerated a list of 69 public services "appropriate for standardization". The strategy was based on a questionnaire prepared for all 13 regions (their regional offices, ${ }^{1}$ excluding Prague), in the case of municipalities a questionnaire was prepared and sent to 728 municipal offices of municipalities existing in one region (Region Vysočina). The survey focused on social services, healthcare, education, culture, transportation, postal and telecommunication services, environment, services of technical infrastructure and information services, and discussed also the potential of various quality methods (EFQM Excellence Model, ISO norms, Common Assessment Framework, benchmarking and BSC, regional standards of social services approved by the community planning initiatives). Submitting report of the strategy required modification of previous documents and recommended further financial supporting of the benchmarking initiatives in the future period $2005-2008$ (see below).

The resolution approved future financial support of the benchmarking project and prioritized central support of creation of voluntary associations of municipalities that would partly address the situation, when more than 6200 municipalities represented a basic administrative level which had less then 500 inhabitants in $60 \%$ of cases (this form of voluntary cooperation was later called as "association of municipalities" as elaborated by working group on small municipalities of the Ministry of Interior, but has not been incorporated into the legislation so far). Till the end of 2005, a specification of information system on availability and quality of local public services was awaited. The proposal was elaborated in cooperation with VŠB - Technical University of Ostrava. Reports of the Ministry of Interior, summarizing progress of Czech public administration reform till the end of 2006, did not speak about the destiny of the public services standardization project. They only mentioned the cooperation within the Visegrad group that aimed at elaboration of analyzes Standardization of public services with regard to use of modern management methods and Analysis of responsibilities of local and regional authorities in V4 countries. No such analyses have been published and no act on public service standardization has been approved and entered into force so far. The issue of standardization of public services and evaluation of public services quality has become topical at least partially among initiatives of the current government.

\footnotetext{
${ }^{1}$ Regional offices and municipal offices are fundamental executive bodies of Czech regions and municipalities, and carry out tasks from the both fields of responsibilities (state administration and self-government).
} 
Public administration quality management is incorporated into the broad strategy of the current government (which gave its resignation in March 26, 2009) Efficient Public Administration And Friendly Public Services - Strategy on Realization of Smart Administration in the Period 2007 - 2015 ("Smart Administration strategy"). This strategy was approved by the government in July 2007. It has been claimed that the Smart Administration strategy is just a special-purpose text elaborated with regard to requirements of European structural funds rather that the real strategy in its nature (eStát, 2007). The strategy works with a hexagon of public administration, among its pillars ICTs can be found together with legislation, organization of its execution, citizen, bureaucrat and finances and also with the emphasis on good governance principles. According to the "situation analysis" of the strategy, the central administrative level is characterized by very limited application of quality management methods like CAF, EFQM, benchmarking and the like, and also by insufficient definition of responsibility for quality outputs. Among the key issues of self-government, particularly deficiencies in managerial capacities of small municipalities, heterogeneous quality of services and low pace of innovation are emphasized, but only in brief and qualitative terms.

According to its authors, the strategy is incorporating the following key principles: openness and transparency, accountability, productivity and effectiveness and also credibility and reliability. The strategy also highlights the role of regulatory reform and reducing administrative burden. It also requires practice of strategic planning in the state administration. The strategy requires implementation of quality management systems in public administration and sociological surveying of citizens' satisfaction with public administration operation, also continual monitoring of quality and performance of public administration shall serve the realization of its aims. The text also highlights experiences with quality management implementation in self-governments. Effectiveness of these partial initiatives shall be measured against indicators - the strategy speaks about "indicators of output" (the number of implemented instruments, number of public authorities with implemented quality systems) and about "indicators of impact" (reduction of operational costs, increase of client satisfaction). No further specification of targets, accountabilities, deadlines and costs is defined in the strategy. Specific deadlines and accountabilities are not specified in the strategy. Its part on evaluation of public administration performance claims a bit contradictorily that "public administration can be considered a public good and it is not possible to identify individual customers, thus evaluation of public administration operation can be based only on subjective indicators which express attitudes of citizens (e.g. confidence in public authorities, satisfaction with services)" (point 3.2.4; p. 30).

The Smart Administration strategy presupposed that the Group for Smart Administration Coordination would be appointed, which shall also inform semi-yearly and annually about the progress. Semi-yearly reports shall be submitted to the Board of deputies (of central authorities, the Union of towns and municipalities of the Czech Republic, the Association of Regions of the Czech Republic and the Economic Chamber) for regulatory reform and efficient public administration with the minister of interior as its chairmen. Annual reports shall be submitted to governments. No such reports have been made available to public so far.

The strategy also assumed that the project schedule would be elaborated within 3 months after the approval of the strategy. The complete schedule of "smartening of 
administration" has not been published yet. In April 2008, the complementary Strategy for development of services for information society was approved, and is currently supplemented by the Integrated Operation Programme ("IOP", approved by the European Commission on 20 December 2007) and the Strategy of eGovernment Implementation in a Territory.

Four priorities of the IOP relate directly to quality management in public administration in particular: a) Priority 1a: Modernising public administration - Convergence Objective; b) Priority 1b: Modernising public administration - Regional Competitiveness and Employment Objective; c) ICT for territorial public administration, and d) Priority 3: Improving the quality and accessibility of public services Convergence Objective.

The primary goal of priorities $1 \mathrm{a}, 1 \mathrm{~b}$ and 2 is to create a more efficient public administration system. This also includes modernising public services at the local and national level through greater use of ICTs that can bring public administration closer to citizens. Definition of aims of these priorities also speaks about implementation of quality management systems and monitoring of public administration performance. Priority 3 aims to improve the quality and availability of public services in the following areas: social services (including social integration of some minorities), public health, employment and security, and risk prevention. These services are of great benefit to Czech citizens, and their efficient delivery depends on good quality public administration at the state, regional and municipal levels. Breakdown of finances of the IOP's e-government components is summarized in the following Table 1.

Table 1: Breakdown of finances of selected priority axis of the Czech IOP (in EUR)

\begin{tabular}{|c|c|c|c|}
\hline Priority Axis & $\begin{array}{c}\text { EU } \\
\text { Contribution }\end{array}$ & $\begin{array}{l}\text { National Public } \\
\text { Contribution }\end{array}$ & $\begin{array}{l}\text { Total Public } \\
\text { Contribution }\end{array}$ \\
\hline $\begin{array}{l}\text { 1a: Modernising public admini- } \\
\text { stration - Convergence Objective } \\
\text { (including 1.1a: Development of } \\
\text { information society in public } \\
\text { administration) }\end{array}$ & 310602133 & 54812141 & 365414274 \\
\hline $\begin{array}{l}\text { 1b: Modernising public admini- } \\
\text { stration - Regional Competitiveness } \\
\text { and Employment Objective } \\
\text { (including 1.1b: Development of } \\
\text { information society in public } \\
\text { administration) }\end{array}$ & 23892472 & 4216319 & 28108791 \\
\hline $\begin{array}{l}\text { 2: ICTs for territorial public } \\
\text { administration } \\
\text { (including 2.1: Introduction of ICTs } \\
\text { in territorial public administration) }\end{array}$ & 170831173 & 30146678 & 200977851 \\
\hline $\begin{array}{l}\text { 3: Improving the quality and } \\
\text { accessibility of public service }\end{array}$ & 545106743 & 96195308 & 641302051 \\
\hline
\end{tabular}


For the creation of Smart Administration in the Czech Republic, the practice of Methodology on inclusion of public in preparation of government's document, which was initiated by former government in 2006 (by its resolution no. 657), but approved by the current government in August 2007 (by its resolution no. 879), is also important. The methodology prescribes general principles of inclusion of the public-like partnership, equal inclusion, information in advance enabling distant access to documents, clarity and comprehensibility, transparency and necessity to give reasons, sufficient inclusion, respecting alternative forms of inclusion, estimation of inclusion costs, annual reporting. The methodology is currently a complement of the document General principles of regulatory impact assessment (RIA) which was approved by government resolution no. 877 in August 2007, but which was also required by the mentioned project management initiative of the former government. Czech RIA methodology that is incorporated into Legislative rules of the Government requires that consultations with public shall become one form of inclusion of public within the process of evaluation of legislation proposals, submitters of regulation shall prove they consult the public before they submit the final proposal.

In 2008, the National quality policy was updated by the document Strategy of National Quality Policy in the Czech Republic for the period 2008 - 2013. This document also speaks about further improvements of public services and public management quality (including the methodical help of the Ministry of Interior, organization of national quality conference and quality awards), and also about further developments of administrative burden reduction which shall refocus on burden on citizens according to current initiatives (Fejtek, 2009).

The organization structure for the public administration area of the Ministry of Interior's has been recently reorganized and a new Department for efficient public administration has been created that is responsible for international cooperation and human resources management, process optimalization and regulatory reform and quality in public administration. It is based on transfers of competences in the field of public administration from the Office of the government to the Ministry of Interior realized in November 2006 (after the change of government).

\subsection{Central government has avoided being highly directive and top-down}

Czech central government has avoided being directive and top-down in its promotion of quality management in public administration. No quality instrument is obligatory for public authorities and the quality management in public administration is based on voluntariness. The only directive feature that has been of a normative nature is the stress on the need to improve the quality of public administration emphasized by the introduced quality policies (if we abstract from quality requirements of financial management stipulated particularly by budgetary rules and financial control provisions, duties related to free access to public information, qualitative requirements imposed on information systems, public procurements and many others). The top-down approach is apparent in various forms of methodical help as introduced below. Also bottom-up interactions emerged - e.g. in the field of e-government, where it is planned to improve the current practices of contact points (the current Czech POINTs and future CzechPOINT@home) by incorporation of good practices of municipal and regional self-governments' projects (e.g. Virtuos, eObec) (Špaček, 2009). The top-down and 
bottom-up meeting point is represented also in various consultations as required for example by the methodology of inclusiveness of public in decision-making processes mentioned before or as it is inevitable for central evaluation of planned, running or realized projects.

\subsection{Central government has been methodically coordinating quality management in public administration}

The methodical guidance of the central government in public administration quality management has been visible as well. Particularly the Common Assessment Frameworks (EIPA, 2002 and 2006) and benchmarking have been methodically elaborated and promoted by the Ministry of Interior in the past, but the official list of quality tools has been growing. The official guide-like information was published on various official quality management websites - particularly on the web pages of the Ministry of Interior, the National quality policy and the Czech Association for Quality.

On the web pages of the Ministry, a special link to "Public administration modernization" existed, which contained also the link to "Quality in public administration". However, the information published here was not systematic and up-todate untill autumn 2007 (Špaček, 2007a). It referred only to two instruments benchmarking and the CAF - and related projects. The link to the CAF led users to brief information on its history and purpose which almost copied the EIPA's introductory texts (EIPA, 2002). Besides, the practice of the instrument was briefly described, but the information referred only to the practice made till 2005. According to the information of that time, the CAF was implemented by 3 public authorities ( 2 regional offices, 1 municipal office) in 2003. In cooperation with the Council of the Czech Republic for Quality, this project was continuing also in 2004 when 26 territorial self-governments took part in it (7 regional offices, 2 "magistrates"1, 17 municipal offices). The only condition required for participation was the commitment to implement the CAF for 3 years which should resulted in its establishment, approving of action plans on improvement and the proposal of self evaluation system of participating public authorities. Three consultation days with experts were funded for each of the participating authority. Experts assisted authorities in self-assessment, during elaboration of the self-assessment report and of their action plans. In 2005 similar project was realized and 23 public sector organisations took part in it (19 municipal offices, 1 regional office and 3 secondary schools).

Web pages of the Ministry of Interior contained also a link to Methodical guide of CAF (EIPA, 2002) situated on the web pages of the National quality policy, but in that time they led to a downloadable document with the old second version of translation of the EIPA's 2002 guide, although the later third version from October 2005 and also the Czech translation of the CAF 2006 were available on the National quality policy's website. Within the Quality in public administration section of the ministerial information the rest of them referred to invitation to the 2nd National quality in public administration conference (which was organised in December 2005), announcement of a declaration of the first year of resort awards of the Ministry of Interior and similar

\footnotetext{
${ }^{1}$ „Magistrát“ is a special name of a municipal office of statutory cities - municipal offices are main executive bodies of Czech municipalities.
} 
announcement informing about 2006's 3rd national quality conference which was in January 2007.

The content of information on the web pages of the Czech Association for Quality was similar - they made methodical information on the CAF, benchmarking and also on the EFQM excellence model available for their users. The web pages referred mainly to the period from 2003 to 2005, but included the year 2006 as well, while informing about the project of the association and the ministry which dealt with the CAF implementation within the central administration authorities (according to the information, only two out of 15 ministries and 11 other central authorities joined the project that time - the Ministry of Finance and the Office of the government of the Czech Republic). A part of the web pages was also devoted to the benchmarking initiative and linked the users with the "CAF database" with the list of its 50 users (8 regional offices, 36 municipal offices, 2 municipal offices of the Municipal parts of Prague and 4 secondary education institutions). The list was not up-to-date that time, however, it did not refer for example to the Regional Office of the Olomoucký region which had implemented the CAF for the third time already in 2006. The list did not contain the Municipal office of Konice and Municipal office of Šlapanice which implemented the instrument in 2006 for the first time. Current informational content focus on the same quality instruments, including offered courses and seminars and also possibilities of managers and system certifications.

Current web pages of the Ministry of Interior offer up-to-date information. Within the sub-section "Public administration" of the menu "About us", there is a link to "Promotion of quality implementation in public administration" which offers users to get to:

a) an article Quality in public administration published in a magazine Public administration (vol. 5, 2008) which summarizes the 4th National quality conference and related quality awards of the Ministry of Interior;

b) information about national conferences on quality in public administration. Here, users can download proceedings of conferences which have been organized by the Ministry since 2005;

c) description of national quality in public administration awards organized by the Ministry of Interior;

d) links to international quality conferences (currently the links refer to 4th and 5th quality conferences in Tampere and Paris, here also the link to inclusion of public into preparation of government documents is accessible which raise a question about the system of information available on the web pages);

e) the section "Methods" (CAF, benchmarking, citizen charters), which are briefly introduced here, and links to further descriptions are available. Links refer to

- CAF 2002 and 2006 translations,

- the Benchmarking project which was launched for the first time in the period 2002 - 2003 with the support of the British Know How Fund, Educational Centre for Public Administration and Statutory city of Ostrava focusing on delivery transportation and disposal of waste in 6 statutory cities (Ústí nad Labem, Plzeň, Jihlava, Pardubice, Ostrava and Havírov). In 2004, another benchmarking project was realized which focused on 29 administrative 
activities of 48 municipalities with extended competences ${ }^{1}$ and was funded by The Canadian Urban Institute (CUI) and The Canadian International Development Agency (CIDA). This project resulted in publication of Benchmarking in public administration and Management of state administration processes (summarizing the practice of the town Vsetín). More recent information about the benchmarking project is not available on the web pages.

- other information on Citizen Charters. Users can get to information on the pilot project Citizen Charters, launched in March 2006 and organized by former Department of public administration modernization of the Ministry of Interior. According to the information available, ten institutions participated in the project (municipal offices of Chomutov, Pelhřimov and Vsetín, Czech Association of Nursing Services, Centre of social and healthcare services Poděbrady, Rest Home for the Retired of Luhačovice, Library of Jiří Mahen Brno, Department of social affairs of the regional office of the Region Zlínský and Transportation company of the capital city of Prague). Participation was free and based on voluntariness. The project was realized with the expert support of the OECD's SIGMA with Elke Löffler and Salvador Parrado as lecturers of 4 passed seminars.

Users of the Ministry's web pages can get to the archived version of their previous form. Here, within the section „Quality in public administration,“ they can also obtain publications Improving customer orientation through service charters (Löffler, Parrado and Zmeškal, 2007), Satisfaction measurement in public administration organizations (Půček, M. et al., 2005a) which introduces practices of the town Vsetín (and which was partly incorporated into the CAF 2002 methodical guide - Půček, M. et al., 2005b), as well as the publication Management of state administration processes (Půček and Kocourek et al., 2004) which is not downloadable from the current web pages (the link is not clickable as it is available on the archived form).

Besides the official translation of CAF's methodologies mentioned, the web pages of the National quality policy contained for example the brochure that referred to a hypothetical case study of the CAF implementation and the use of the tool in various areas (in self-governments, schools or central administrative authorities). Methodical guide to BSC or ISO norms (particularly the 9000's series) in public sector are also available. Users can also download a handbook Models of Measurement and Improvement of Customers Satisfaction (Nenadál, J. et al., 2004) introducing methodologies related to customers as well as employees. Among the available service "Search for / Databases" a special link to "Public administration" has been made available. Currently, it refers to publications and links to other websites, but at the time

\footnotetext{
${ }^{1}$ Municipalities with extended competences execute the largest amount of state administration in Czech municipal administration system. These municipalities represent the youngest category of municipalities that has been created in relation to the abolishment of district authorities and the transfer of their competencies to municipal level) since January 2003. Czech administrative system was introduced for example in Špaček, D., Špalek, J. (2007). Communication and Electronic Public Administration: Some Issues in the Context of the Czech System of Public Administration. In Nemec, J. (Ed.). Lessons and Recommendations for Improvement: Central and Eastern European Public Administration and Public Policy, Bratislava: NISPAcee, pp. 217 - 238.
} 
of preparation of this article, only the links "magazine Modern municipality" and "European Institute of Public Administration" were working, the others ("Model EFQM within the project of Modernization of central state administration", "Ministry of Interior - public administration", "Project of Implementation of EFQM model by Police of the Czech Republic") were not.

There is no list published for example by the Ministry of Interior that would inform about practice of various quality methods in Czech public administration. Most probably it is also caused by the voluntariness of quality management tools implementation which caused problems for EIPA's evaluation of the CAF use (EIPA, 2003 and 2005).

2.4 There are several national quality awards in the Czech Republic organized according to the national quality policy during national conferences on quality in public administration

Certain features of the "control-oriented approach" are embedded in various awards initiatives that have been realized in the Czech Republic. The text below introduces particularly the National Quality Award and Resort Awards of the Ministry of Interior which represent the most influential prizes that can be awarded in the Czech public administration, although public managers can be awarded also a prize "Quality Manager of the Year" as organized by the Czech association for Quality (in 2010 the 9th year of this competition was announced).

The National policy on quality presupposes (since 2001) the National Quality Award among its instruments. Since 2006, this award has been separately specified for the private sector and public sector organisations (since 1995 similar award was described only for the purposes of private sector organisations). Since then, candidates for the award from public sector organisations have been required to implement EFQM excellence model or the CAF instrument, since 2009 the category Corporate Social Responsibility (CSR) has been added, too. The announcer of the award and the control body is The Council of the Czech Republic for Quality; it also appoints and examines evaluators of self-assessment reports and supplementary materials of applicants for the competition required for application for the award.

A similar platform is used in the case of the Resort Awards of the Ministry of Interior. In the case of 2005, 2006 and 2007 ministerial awards competition, applicants were awarded in the following three categories during the national conferences on quality in public administration - "Organization that improves public service quality" (the bronze category), "Organisation of good public service" (the silver category), and the third category - "Resort award of the Ministry of Interior for an innovation in territorial public administration".

1) The first award category (i.e. the bronze) required a true evidence on initial implementation of some of the standard instruments of public service quality improvement, e. g. the CAF, EFQM excellence model, ISO 9000 or 14000, BSC, benchmarking cycle or other instruments (in 2006 the level $\mathrm{C}$ of the Local Agenda 21 and community planning were added to the list that expressively enumerated the methods) which might lead to public service quality improvement. Organizations could be awarded even in the case of "modest results". 
2) The second award category (i.e. the silver) could be received by institutions which gave a true evidence on

- two years CAF implementation with the minimum score 2.4 in the final evaluation based on the Czech CAF methodology, or the minimum score 3.0 when calculated like in EIPA's methodology (complex evaluation of 27 criteria);

- EFQM implementation with the minimum score of 250 points;

- benchmarking cycle realization and the compliance with 5 sub-criteria (plan of improvement; multi-criteria performance indicator higher than 0 ; positive results of realized employee and citizens/clients survey; action plan that clearly defines the area of change, goals, justification, concrete measures, time scale; innovative approach - at least one example of good practice); or

- $\quad$ CSN EN ISO 9001 certification, including the plan of improvement and positive results of employees and citizens/clients surveys.

For the purposes of 2006 awards the requirements changed, as in the previous category due to the enumeration of the Local Agenda 21 in the list (level A or B was required together with the elaborated improvement action plan and positive results of citizen/customer and employee satisfaction measurement). The 2006 award also required that for the purposes of this category self-assessment reports would be assessed by an external independent evaluator during the site visit, in the case of application of Local Agenda 21 implementation applicants had to be evaluated by the Working group on Local Agenda 21 of the Government's Council for Sustainable Development.

3) Criteria of the third supplementary award category - The Award for innovation referred to non-traditional solution that contributed to activities of authorities and public service delivery efficiency which may become good practice examples for other organisations. Self-assessment reports of assistants had to describe the status quo and characteristics reached in order to show improvements. An applicant was also required to present their practice during the national conference.

In 2008, requirements of the ministerial resort awards were modified and the golden category award "The Winner of National Quality Award" was initiated - since that time awards of the Ministry and National quality awards of the Council have been interconnected for the purposes of golden category awards. Particularly applicants implementing the CAF have had to meet stricter requirements since that time. The same expert external evaluators have been used in both competitions since then. In 2008, first award category required that applicants were awarded the second award category previously and that they also implemented CAF 2006 (reaching at least 55 points during using the fine-tuned evaluation as described in this new methodology - EIPA, 2006). In the case of silver prize, at least two years implementation of CAF was required together with the minimum score of 40 points based on the fine-tuned scoring, self-assessment report elaborated according to the CAF 2006 methodology, related action plan and proving of meeting the previous action plan on improvements. The bronze prize could be awarded if total score of 25 was reached during CAF 2006 implementation regardless the way of giving scores (traditional or fine-tuned), applicants had to submit self-assessment reports as well as followed-up action plans. For the purposes of the 
2008's ministerial awards the EFQM excellence models was displaced, only applicants for the National quality award organized by the Council could be awarded in the case of implementation of this system.

In February 2009, the fifth national conference on quality in public administration was organized and similar framework was used also in the case of quality award in 2010. Again, the EFQM excellence model was displaced. Among the list of expressively enumerated methods the implementation of the environmental management EcoManagement and Audit Scheme (EMAS) and its registration by the EMAS Agency was also required. Propositions of the awards described only bronze, silver and innovation awards similarly to the awards scheme of 2008, the golden category which was organized together with the competition National Quality Awards as in the previous year is not described in the awards specification.

\section{Conclusions}

The paper clearly shows that quality management is not a forgotten topic in the Czech public administration reform and modernization policies, as well as in practices of Czech territorial (municipal and regional) self-governments. Czech central government has not been passive in promotion of quality management in general, neither in public administration. Its approach is more converging to Löffler and Vintar's 'hands-on' and supportive approach rather than the one that aims for control-orientation. No quality instrument is obligatory for public authorities and the quality management in Czech public administration is based on voluntariness. The only directive feature that has been of a normative nature is the stress of central policies on the need to improve the quality of public administration (if we abstract from quality requirements specified in some special acts as outlined above). Central government has focused particularly on quality management promotion (also through national quality conferences and quality awards schemes) and methodical help intensively using also electronic channels (websites) for information dissemination.

The approach of Czech central government to promotion of quality management in public administration has the following characteristics:

- governments approved national policy and strategies on quality support in public administration

- central government has avoided being highly directive and top-down

- central governments have been methodically coordinating quality management in public administration

- there are several national quality awards in the Czech Republic organized according to the national quality policy during national conferences on quality in public administration. 


\section{References}

BEAM, G. (2001). Quality Public Management - What It Is and How It Can Be Improved and Advanced. Illinois: Burnham Inc., Publishers.

CADDY, J., VINTAR, M. (2004). Building Quality into Public Administration. In Caddy, J., Vintar, M. (Eds.), Building better quality administration for the public: Case studies from Central and Eastern Europe. Slovakia: NISPAcee.

DENHARDT, J., V., DENHARDT, R., B. (2003). The New Public Service - Serving, not Steering. New York: M. E. Sharpe.

EIPA. (2002). CAF Brochure - 2002. Retrieved March 23, 2006 from http://www.eipa.eu/CAF/Brochure/CAF2002_Eng.pdf.

EIPA. (2003). Study on the use of the Common Assessment Framework (CAF) in European Public Administrations. Retrieved August 25, 2008 from http://www.eipa.eu/CAF/Articles/CAF_ENG_DG.pdf.

EIPA. (2005). Study on the use of the Common Assessment Framework in European Public Administrations. Retrieved August 25, 2008 from http://www.eipa.eu/CAF/Articles/CAFpublication_2005_EN_V01_7dec05.pdf.

EIPA. (2006). CAF Brochure - 2006. Retrieved August 25, 2008 from http://www.eipa.eu/CAF/CAF_2006/Brochures/English_2006.pdf.

eSTAT. (2007). Smart Administration - reforma nebo jen pozlátko pro evropské úredníky?. Retrieved May 5, 2010 from http://www.estat.cz/smart-administrationreforma-nebo-jen-pozlatko-pro-evropske-uredniky2.html.

FEJTEK, P. (2009). Byrokratická zátěž občanů: Přístupy k jejímu měření a snižování. In Veřejná správa, vol. 6, Ministerstvo vnitra. Pp. 14, 16 - 17.

FLYNN, N. (2002). Public Sector Management. Essex: Pearson Education Limited.

GASTER, L., SQUIRES, A. (2003). Providing Quality in the Public Sector. Maidenhead: Open University Press.

HUGHES, O. E. (2003). Public Management and Administration - An Introduction. New York: Palgrave MacMillan.

HUMPHREYS, P. C. Improving the Quality of Services Delivered in Ireland: Different Approaches to the Challenge of Change. In Löffler, E., Vintar, M. (Eds.), Improving the Quality of East and West European Public Services. Aldershot: Ashgate Publishing. Pp. $57-71$.

LÖFFLER, E. (2002), Defining and Measuring Quality in Public Administration. In Caddy, J., Vintar, M. (Eds.), Building better quality administration for the public: Case studies from central and Eastern Europe. Bratislava: NISPAcee 2002. Pp. 15 - 34.

LÖFFLER, E., PARRADO, S., ZMEŠKAL, T. (2007). Improving customer orientation through service charters. Ministerstvo vnitra ČR and OECD. 
LÖFFLER, E., VINTAR, M. (2004). The Current Quality Agenda of East and West European Public Services. In Löffler, E., Vintar, M. (Eds.), Improving the Quality of East and West European Public Services. Aldershot: Ashgate Publishing. Pp. 3 - 19.

MILAKOVICH, M. E. (1995). Improving Service Quality - Achieving High Performance in the Public and Private Sectors. Florida: St. Lucie Press, Inc.

NENADÁL, J. et al. (2004). Měřní v systémech managementu jakosti. Praha: Management Press.

PU゚ČEK, M. et al. (2005a). Měrení spokojenosti v organizacích veřejné správy - soubor př́kladi̊, Praha: Ministerstvo vnitra ČR.

PŮČEK, M. et al. (2005b). Jak efektivně uplatnit CAF v samosprávných úr̆adech. Praha: Národní politika podpory jakosti.

PŮČEK, M., KOCOUREK, S. et al. (2004). Řízení procesů výkonu státní správy. Praha: Ministerstvo vnitra $\breve{C}$.

SCHNEIDER, B., WHITE, S. (2004). Service Quality - Research Perspectives. California: Sage Publications, Inc.

ŠPAČEK, D. (2007a). Common Assessment Framework: potential and factual issues in the Czech administrative practice. Organizaciju vadyba: sisteminiai tyrimai, vol. 43. Pp. $163-182$.

ŠPAČEK, D. (2007b). Sebehodnocení podle CAF a vyhodnocování spokojenosti klientů veřejné správy. In Škarabelová, S. (Ed.), Problematika zabezpečování veřejných služeb. Brno: Masarykova univerzita, Ekonomicko-správní fakulta. Pp. 156-165

ŠPAČEK, D. (2009). Czech POINTS - The Czech Showcase?. In State and Administration in a Changing World. Bratislava : NISPAcee, 27 pages.

ŠPAČEK, D., NUNVÁŘOVÁ, S. (2009). Quality Management and Citizens' Satisfaction - Selected Practice of Czech Public Administration. In State and Administration in a Changing World. Bratislava : NISPAcee, 24 pages.

ŠPAČEK, D., ŠPALEK, J. (2007). Communication and Electronic Public Administration: Some Issues in the Context of the Czech System of Public Administration. In Nemec, J. (Ed.). Lessons and Recommendations for Improvement: Central and Eastern European Public Administration and Public Policy, Bratislava: NISPAcee. Pp. 217 - 238.

ZEITHAML, V. A., PARASURAMAN, A. (2004). Service Quality. Cambridge, Massachusetts: Marketing Science Institute. 


\section{PROMOTION OF QUALITY MANAGEMENT IN PUBLIC ADMINISTRATION}

\section{- THE APPROACH OF CZECH CENTRAL GOVERNMENT}

\section{David Špaček}

Masaryk University, Faculty of Economics and Administration, Lipová 41a, Brno, Czech Republic, e-mail: david.spacek@econ.muni.cz

Abstract: The first part of the paper summarizes the specifics of quality and its management in public administration. The second part introduces the approach of the Czech central government to quality management promotion in public administration with regard to classification of approaches proposed by Löffler and Vintar (2004). The approach is more converging to Löffler and Vintar's 'hands-on' and supportive approach rather than to passive or control-orientation approaches.

Key words: quality management promotion, public management, Czech public administration reform.

JEL Classification: H79

DOI: $10.2478 / \mathrm{v} 10135-011-0002-2$ 